\title{
Systemic risks of genetically modified crops: the need for new approaches to risk assessment
}

\author{
Hartmut Meyer
}

\begin{abstract}
Purpose: Since more than 25 years, public dialogues, expert consultations and scientific publications have concluded that a comprehensive assessment of the implications of genetic engineering in agriculture and food production needs to include health, environmental, social and economical aspects, but only very few legal frameworks allow to assess the two latter aspects. This article aims to explain the divergence between societal debate and biosafety legislation and presents approaches to bring both together.

Main features: The article reviews the development of biosafety regulations in the USA and the EU, focussing on diverging concepts applied for assessing the risks of genetically modified organisms (GMOs).

Results: The dominant environmental risk assessment methodology has been developed to answer basic questions to enable expedient decision making. As a first step, methodologies that take into account complex environmental and landscape aspects should be applied. Expanding the scope of risk assessment, more holistic concepts have been developed, for example the Organisation for Econonomic Co-operation and Development (OECD) concept of systemic risks which includes socio-economic aspects. International bodies as the OECD, the Convention on Biological Diversity (CBD) and the European Union (EU) have developed the Strategic Environmental Assessment (SEA) as an instrument that includes the additional aspects of risk assessment as demanded by many stakeholders. Interestingly, there had been no attempts yet to link the existing frameworks of GMO risk assessment and SEA.
\end{abstract}

Conclusions: It is recommended to adapt current models of SEA to assess the systemic risks of GMOs. It is also suggested to revise the EU GMO legislation to promote the inclusion of SEA elements.

\section{Genetic engineering in agriculture: impacts and restraints}

The first genetically modified organisms (GMO) deregulated and commercialised was the Flavr Savr tomato in 1994 in the USA, which did not prove to be commercially viable. US genetically modified (GM) agriculture actually started with Bt cotton planting in 1995, but it only was the introduction of Roundup Ready soybeans in 1996, being exported worldwide as basic ingredient for the feed and food industry that initiated the worldwide public debate on the use of GM crops. Meanwhile, James reports that 15 countries grow more than 50,000 ha of GM crops each with a sum of 133.9 million hectares [1]. According to FoEI-pointing to the fact that the data presented by James are mostly based on

Correspondence: hmeyer@ensser.org

Federation of German Scientists (Vereinigung Deutscher Wissenschaftler, VDW), In den Steinäckern 13, Braunschweig, 38116, Germany personal communiclations by representatives of the biotechnology industry, which also funds his work-this area equates to $9.2 \%$ of the arable land worldwide [2]. Ninety-two percent of this area is located in five countries (USA, Brazil, Argentina, India, Canada). GM crop agriculture relies on five plant species (soybean, maize, canola, sugar beet and cotton) predominately producing animal feed, ethanol and fibres in high-input farming systems. Based on the data provided by James, it can be concluded that GM food products mainly comprise sugar, high-fructose corn syrup, soy protein, lecithin or different oils [1]. Some GM maize varieties can be used for direct consumption as, for example, in South Africa. In the USA, some GM papaya is marketed. The range of new properties used in GM crop agriculture is essentially limited to two features: resistance against the herbicides glyphosate and glufosinate and production of

\section{SpringerOpen ${ }^{\circ}$}

(C) 2011 Meyer; licensee Springer. This is an Open Access article distributed under the terms of the Creative Commons Attribution License (http://creativecommons.org/licenses/by/2.0), which permits unrestricted use, distribution, and reproduction in any medium, provided the original work is properly cited. 
Bacillus thuringiensis (Bt) endotoxins that are used to kill specific lepidoptera and coleoptera larvae (Table 1).

The main bottleneck for developing a higher variety of commercially viable products seems to be the limited potential of the technology itself. Complex characteristics of plants as drought or saline resistance are based on reactions of the plant organism at several, including but not only the genetic level. Many-still unknowngenes may play a role in the response to environmental condition. The application of genetic engineering alone might not lead to the improvement of such complex traits [3-5]. Only GM plants possessing genes-which are supposed to work in isolation from the plant's metabolism, as the herbicide resistance and Bt genes-are used commercially. Additionally, two GM plant types possessing pathogen-resistant genes which are supposed to interact with an invading organism could be developed into a commercial product: GM virus-resistant papaya and squash grown on 2,000 ha each in the USA [6]. Until the end of 2004-which should leave enough time for the development of commercial seed until 2009-the U.S. authorities approved 877 field trials with plants that were supposed to be virus resistant (988 until the end of 2009). Experiments with GM plants that were supposed to be resistant against fungi did not result in any commercial product yet, 622 field trials were approved in the USA until the end of 2004 (854 until the end of 2009). The main blocks to market fungi-resistant GM plants are the lack of deeper understanding of the molecular plant-fungi interactions and the unsatisfactory levels of resistance $[7,8]$.

Stein and Rodríguez-Cerezo predict that a turning point has been reached in the limited commercialisation of GM traits [9]. The authors estimate that in 2015 the number of traits in farmers' fields might quadruple to 120 , amongst them 17 soy traits (12 herbicide resistant, three altered oil composition, two pest resistant) or 15 rice traits (six insect resistant, four pest resistant, three herbicide resistant, two $\beta$-carotene). This development would mainly increase the number of traits mentioned above to 114 . Only six traits aim at influencing more complex characteristics as drought resistance in maize while they still rely on single gene alterations.

Table 1 Overview on deregulated and cultivated GM traits in the USA 1992-2009

\begin{tabular}{|c|c|c|c|}
\hline Phenotype & Plant species & $\begin{array}{l}\text { Number of } \\
\text { deregulated traits }\end{array}$ & $\begin{array}{l}\text { Transgenic species in } \\
\text { cultivation }^{\text {b }}\end{array}$ \\
\hline Herbicide tolerance & & 48 & \\
\hline Glyphosate & $\begin{array}{l}\text { Canola, cotton, maize, soy, } \\
\text { sugar beet }\end{array}$ & 15 & Yes \\
\hline Glufosinate & $\begin{array}{l}\text { Canola, cotton, maize, rice, soy, } \\
\text { sugar beet }\end{array}$ & 27 & Yes, not all species \\
\hline Others & Cotton, flax, maize, soy & 6 & Yes, not all species \\
\hline Insect resistance & & 41 & \\
\hline Corn borer & Maize & 26 & Yes \\
\hline Corn root worm & Maize & 3 & Yes \\
\hline Colorado beetle & Potato & 11 & No \\
\hline Other & Tomato & 1 & No \\
\hline Altered fruit ripening & & 40 & \\
\hline Flavr Savr & Tomato & 33 & No \\
\hline Other & Tomato & 7 & No \\
\hline Virus resistance & & 12 & \\
\hline Papaya ringspot virus & Papaya & 3 & Yes \\
\hline $\begin{array}{l}\text { Cucumber mosaic virus, zucchini yellow mosaic virus, } \\
\text { watermelon mosaic virus } 2\end{array}$ & Squash & 2 & Yes \\
\hline potato leaf roll virus, potato virus $Y$ & Potato & 6 & No \\
\hline Plum pox virus & Plum & 1 & No \\
\hline Male sterility & Cichoria, canola, maize & 8 & No \\
\hline Altered oil composition & Canola, soy & 5 & No \\
\hline Higher lysin content & Maize & 1 & No \\
\hline Lower nicotine content & Tobacco & 1 & No \\
\hline
\end{tabular}

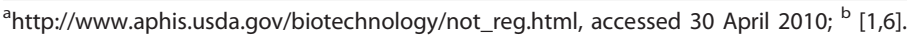

Source: own compilation. 


\section{Development of regulatory biosafety frameworks Asilomar conference}

It was U.S. scientists working in the fields of cancer research and molecular biology being concerned about the potential health risks of their work who started the scientific debate on the pros and cons of GMOs [10]. The participants of the 1973 Gordon Conference on Nucleic Acids drafted a resolution, which warned about the potential health risks of hybrid DNA molecules and called successfully upon the National Institutes for Health $(\mathrm{NIH})$ to develop safety guidelines [11]. An international conference to support the development of safety standards was announced and even moratoria on certain types of experiments suggested [12]. In spring 1975, participants of the Asilomar Conference recognised that more than health problems might arise from the industrial, medical and agricultural application of genetic engineering, but they restricted their debates on this risk issue. While the conference concluded that mechanisms of self-control and voluntary guidelines should be the basis for the development of the technology, calls for a stricter and legally binding governmental oversight were launched during the emerging public debate in cities as Cambridge, Massachusetts, harbouring major research institutions [12,13]. Envisaging a growing unease of the public, prominent molecular biologists soon questioned the value of the early risk debate [14-16].

\section{Emerging biosafety systems in the USA}

When Cohen reported that his research enables scientists to cross the species barriers, suggesting the invention or creation of new species, U.S. politicians started, soon after, to draft regulations for the application of GMOs [17]. This in turn alerted those scientists that envisaged large economic potential based on their work and patents, and in 1977, a draft law for GMO regulation was stalled when Cohen convinced politicians that the results of the new technology could also have appeared in nature. Expecting a revolution in biology and an immense impact on business, genetic engineering was declared as equivalent to conventional breeding methods, meaning a GMO is not a new organism with unforeseeable risks and does not require specific regulation [18]. In 1976, the NIH adopted guidelines, which set up a system based on biological and physical containments. Later, the U.S. National Research Council formalised the risk assessment approach [19]. When in 1983 the first GM bacteria and plants were released in field trials in California, the existing health protection guideline concept was applied to assess possible environmental risks [20]. The U.S. has opted using existing frameworks to set up a consultation system. ${ }^{1}$ Nowadays, genes and proteins that render herbicide tolerance to
GM plants are assessed and deregulated according to the rules for food additives; plants possessing Bt genes and proteins fall under the pesticide approval rules and growth hormone-producing fish has to be checked under the procedures for approval of animal drugs. Two recent U.S. law cases stated that the procedure agreed upon by the authorities and the applicant for deregulating herbicide-resistant golf lawn grass and alfalfa were faulty. A more rigid assessment under the norms of U.S. environmental laws had to be conducted. With these court decisions it seems that GM plants that can interact substantially with wild or domesticated genetic resources via pollen flow must undergo a more detailed risk assessment in the USA as, for example, GM soy or maize. It remains open until a final supreme court decision, if and how these court cases will influence the future GM crop regulation in the USA.

\section{Biosafety frameworks at the European and UN level}

In contrast to the situation in the USA, the debate in EU countries went beyond expert circles and involved more NGOs and citizen groups. It also lacked the strong focus on emerging commercial prospects of genetic engineering. While the model of the NIH guidelines was adopted by many European governments, the emerging public debate quickly reached the decision that an overarching, specific legal framework was necessary due to the novelty of GMOs [18,21]. The first biosafety laws were adopted in Denmark in 1986 and Germany in 1990, EU biosafety regulations followed in $1990 .^{2}$ Since that time, the concept of the European biosafety legislation is that the properties and behaviour of organisms which "genetic material has been altered in a way that does not occur naturally by mating and/or natural recombination" cannot be predicted from the current experience with and knowledge about the parent organism. Although this socalled process-based system was developed under the umbrella of the community environmental law it did not adapt existing instruments for assessing environmental risks of technical and industrial activities, e.g. environmental impact assessment, but kept the GMO risk assessment approaches that had been developed in the context of the technology development.

In 1995, the negotiations of international binding biosafety rules under the framework of the CBD) started, which resulted in the Cartagena Protocol on Biosafety $(\mathrm{CPB})^{3}$ adopted in 2000 [22]. Comparable to the EU, the $\mathrm{CPB}$ adopted a process-based type of GMO regulation. As the Biosafety Clearing House of the CPB and other data banks show, legally binding specific biosafety legislation are currently in force or under development in 112 out of 200 countries:

- Seventy-nine states with legislation in force (amongst them 33 industrialised countries) 
- Thirt-three states with legislation in development

- Fifty states with a national biosafety framework based on the $\mathrm{CPB}$

- Eleven states having ratified the $\mathrm{CPB}$

Countries, which so far do not follow the process-based approach to biosafety legislation, are the USA and Canada. Twenty-five states have no biosafety system at all.

\section{Conflicting concepts for assessing environmental risks of GMOs \\ The "ecotoxicological approach" versus the \\ "environmental approach"}

Ever since the first GMOs were released, it was discussed whether it is justifiable to apply methods developed for toxicology assessment of chemical substances to viable and reproducible organisms or if new methods had to be developed. The differences between the testing approaches were brought to a wider public when Hilbeck et al. and Losey et al. for the first time showed negative effects of Bt toxins and Bt maize pollen on ecologically relevant non-target organisms in laboratory experiments at a time when Bt crops where already deregulated and cultivated commercially in the USA [23-25]. The U.S. authorities did not require an ecologically oriented laboratory or even field test for the deregulation of Bt cotton in 1995 [26]. The respective risk research and assessments were largely and still are based on ecotoxicological laboratory approaches. Standard protocols and organisms are used due to the good reproducibility of experiments, easy breeding of those organisms and low costs of the work. The two different concepts for GMO risk assessment were named "ecological approach" and "(eco)toxicological approach" $[27,28]$. According to EFSA, the current arguments and representatives are presented by Andow et al. and Romeis et al. [29-31].

Hilbeck et al. questioned whether the design of these ecotoxicological tests would contribute to assessing the ecological risks of Bt crops [32]. For example, the water flea Daphnia magna was exposed to Bt maize pollen and the measurement of "no effects" was judged as "no risk" although the Bt toxin contained in the pollen will not dissolve in the water and Daphnia cannot eat pollen. Similarly "no effect" results with the earthworm Eisenia fetida were accepted although there was no proof that the worms actually had taken up the toxin in the feeding trials. Apart from questionable test designs, it is known that, for example, the widely used earthworm Eisenia fetida does not live in agricultural ecosystems [33]. The criticism on using environmentally irrelevant organisms and ill-designed tests added to the existing uncertainty on how to measure "indirect effects", e.g. the effects of the herbicides used together with herbicide tolerant crops, as demanded by the legal framework, how to deal with the foreseeable EU-wide use of antibiotic marker genes in foodstuff made out of GM crops containing these transgenes and how to evaluate the research work pointing to considerable gene flow in GM canola [34]. It was against this background that the EU environmental council ${ }^{4}$ declared the stop of all pending GMO application procedures in 1999 until the EU biosafety regulations had been revised.

\section{Different reactions on the new EU biosafety framework}

This scientific dispute in combination with societal and economic impacts influenced the revision of the EU GMO regulations [35]. The new EU biosafety Directive 2001/18/EC supports the ecological approach and prescribes a more detailed environmental risk assessment (ERA), establishes the precautionary principle as baseline for decision making and also serves as ERA reference for the regulation (EC) 1829/2003 on GM food and feed market approval. ${ }^{5}$ The five steps of current risk analysis procedures (hazard identification, exposure assessment, consequences assessment, risk characterization, mitigation options) were accepted as valid for GMOs, but methodologies and interpretations should be adapted to meet the specific features of living organisms and their interactions with the receiving environment [36-39]. Although Directive 2001/18/EC establishes a new framework for ERA prescribing the testing of the GMO as such (not only of the new genes and proteins) or the consideration of the receiving environment (not only some field trial locations as basis for an EU-wide approval), a review of the soil ecotoxicological tests presented in GMO dossiers concluded that they do not reflect the new legal requirements [40]. These authors, in line with Andow and Hilbeck and Snow et al., emphasise that it is crucial not to rely on standard test species only but to choose test species representative of the agro-ecological environments in which the GM plants will be grown $[41,42]$. A recent EFSA Scientific Opinion elaborates extensively on the issue of species selection that should take into account the "ecological relevance of the species, susceptibility to known or potential stressors, anthropocentric value, testability, exposure pathways" of non-target organisms [29]. Furthermore, experiments with the actual GM crops at different levels of complexity have to be performed as basis for a sound risk assessment [43].

The stated deficits in the GMO dossiers and a series of publications that argue against a wider application of the ecological approach in ERA show that the implications of the new legal framework are seen critical by developers of GM crops and scientists advocating their use. A scientist of Syngenta states that "environmental risk assessment research has often attempted to describe 
the multitude of potential interactions between transgenic plants and the environment, rather than to test hypotheses that the cultivation of transgenic plants will cause no harm." [28]. The ecological approach obviously supports decision makers against approving GM crops, and ecologists advocate even more research into complex ecological interactions. Raybould addresses not only the methodology of ERA but also the central normative problem in the relationship between risk research and risk assessment: who determines what kind of hypothesis has to be tested, which level of scientific knowledge and certainty is needed before making decisions, and where is the border between "need to know and nice to know".

Developers of GM crops suggest different approaches on how to accelerate the GM crop approval under the new EU system. One basic suggestion of Raybould is that "ecologists must avoid the temptation to test null hypotheses [of no difference between a transgenic plant and a non-transgenic comparator]" but test risk hypotheses on adverse effects of GM crops on environmental goods and processes that need to be protected [28]. With regard to the EU political and legal background, it seems questionable if this approach will lead to the desired outcome. First, the necessary decisions on protection aims have not yet been taken in the EU. Furthermore, the suggestion does not reflect the concept of the EU biosafety legislation saying that the application of gene technologies might lead to new risks and that, therefore, the first requirement of risk assessment is to test the above-noted null hypothesis on unforeseen differences between the GMO and its parents.

The second suggestion of private sector representatives of the ecotoxicological approach is that field tests should not be a prerequisite for GMO approvals, but should only be demanded when literature studies or ecotoxicological experiments show significant negative effects [44]. A scientist of Monsanto suggests that this model should also be applied to his company's droughtresistant GM maize, a trait that until now was seen as model case for more complex, ecologically oriented risk research and assessment [45]. This approach enabling a more expedient approval of GM crops was supported by U.S. and EU governmental risk assessors and public scientists in a joint publication on risk assessment of non-target effects of Bt crops and accordingly shaped the draft guidance on GM crop risk assessment presented by the European Food Safety Authority [31,46].

\section{Normative dimensions of risk assessment}

In those discussions, it became apparent that ERA steps 1 and 5 as described by Hill are not restricted to the application of scientific methodology but must also be based on substantial normative and thus value-loaded decisions [37]. Many authors state that step 1 indeed needs to be broadened and developed into a "Problem Formulation". Scientists advocating the ecological approach developed the problem formulation and option assessment (PFOA) tool, based on stock-taking exercises, stakeholder consultation and broader public participation procedures [47]. The PFOA was tested in developing countries not only to improve the ERA but as a technology assessment tool following the suggestion of OECD [48-51]: "Analyses leading to risk management decisions must pay explicit attention to the range of standpoints, in particular in situations with a high potential for controversy. This is often best done by involving the spectrum of participants in every step of the decision-making process, starting with the very formulation of the problem to be analysed. Introducing more public participation into both risk assessment and risk decision-making would make the process more democratic, improve the relevance and quality of technical analysis, and increase the legitimacy and public acceptance of the resulting decisions."

When Raybould reflected on the UK farm scale evaluation of GM herbicide tolerant (GMHT) crops, he illustrated clearly that the problem formulation (step 1) strongly depends on the respective stakeholder interests $[52] .^{6}$ From a herbicide-producing company's perspective, the preservation of arable weeds presents no value and the aim of any GMHT crop system is to reduce their abundance; from a nature conservation perspective, however, arable weeds are a valuable part of biodiversity that should not be eradicated in agro-ecosystems.

While this attitude of a scientist from the private sector is not very surprising, it can be observed that public scientists in application-oriented fields as plant biotechnology tend to adopt comparable attitudes [53]. Kvakkestad et al. interviewed 62 Scandinavian scientists on their perspectives with regard to the deliberate release of GM crops against their professional and funding backgrounds [54]. Two perspectives prevail: perspective 1 is held by many publicly funded scientists who emphasised that the environmental effects from GM crop are unpredictable, and perspective 2 is held mainly by scientists from the biotechnology industry who emphasise that GM crops present no unique risks. No ecologist associated himself with perspective 2. Publicly funded scientists that do not hold above perspective 1 but promote biosafety systems that establish enabling environments for the adoption of GM crops are meanwhile organised in lobby groups as the Public Research and Regulation Initiative, ${ }^{7}$ funded by a former Syngenta manager [55].

Also, step 5 and the activities leading to the final decision involve much more than pure science. Millstone et al. stated that the attitude of authorities to deal 
"asymmetrically" with research that showed negative effects compared to research that could not show negative effects is interpreted by the public as support of the authorities for the developers of GMOs [56]. The Cartagena. Protocol on Biosafety explicitly refers in its Risk Assessment Annex to this common attitude when it obliges its member states to consider that "lack of scientific knowledge or scientific consensus should not necessarily be interpreted as indicating a particular level of risk, an absence of risk, or an acceptable risk". This formulation had been agreed upon by the negotiators as a way on how to implement the precautionary principle in GMO risk assessment and decision making [57]. To address these normative issues in a democratic and socially acceptable way, new processes are needed, which must secure that the point of view of every stakeholder can have its influence on problem formulation in risk assessment and the final decision making $[58,59,51,60]$.

\section{Broader approaches for assessing the implications of GM crop agriculture}

New risk concepts that lay the ground for more holistic approaches to assess risks beyond the traditional scope of GMO legislation have been suggested to solve the above-described disputes. In 2003, the OECD International Futures Programme concluded that the classical risk assessment concepts are not suitable to deal with risks that realise themselves or excerpt their influence in larger spatial and/or temporal dimensions [51]. OECD also suggested that the basis of scientific disciplines has to be broadened because "many risk models assume that a hazard is linked from a well-identified source to a single endpoint in more or less linear fashion. That could well prove a seriously flawed assumption if a number of complex evolving factors are at work". In the GMO context, the OECD model of "Systemic Risks" would include the assessment of socio-economic issues as coexistence, patents on seeds and seed monopolies or induced herbicide resistance in weeds.

The OECD concept of systemic risks and risk governance was quickly taken up by scientists and institutions connected with the bank and insurance sector or concerned about the complex effects of chemical pollutants, pandemics or climate change on human health and public health systems [61-64]. With regard to systemic risks of commercial GM crop agriculture, the German research project "GenEERA" developed methods to improve the current ERA with the aim to support the assessment of socio-economic aspects, specifically focussing on the issue of coexistence. Breckling et al. developed geostatistical models to forecast long-term and regional effects of commercial plantation of GM rape seed that cannot be assessed through experimental approaches $[65,66]$. Complemented by models that allow to scale-up the effects of climatic, crop cultivation, and population parameter on regional GM rape seed dispersal, the project could show that the plantation of GM rape seed would cause systemic risks [67-69]. Model calculations for regions in Northern Germany showed that due to the persistence of transgenes in the soil seed bank 3 years after GM rape seed cultivation, 90\% of the fields brought harvests with a GM content above the $0.9 \%$ labelling threshold. After 10 years, this percentage was still 5\% [70]. Farmers in the state of SchleswigHolstein, the main rape seed producing region in Germany, would face major external costs to keep the GM content of their harvest below $0.9 \%$ if GM rape seed planting would gradually increase to cover $50 \%$ of the acreage within 10 years [71]. The follow-up project GeneRisk $^{8}$ will adapt these methodologies for assessing systemic risks to Bt maize, complemented by participative approaches involving local stakeholders (results not published yet).

\section{The application of socio-economic assessments}

Besides the issue of coexistence, other socio-economic implications are raised in the GMO debate [72]. Still, most legal frameworks do not allow their inclusion in approval process. Governments of industrialised countries and technology developers argue that the methodologies that need to be applied, which would go beyond the current "science-based" risk assessment, are not harmonised and might lead to intransparent and arbitrary decisions $[73,74]$. Examples for systematic socio-economic assessments are therefore rare; the available literature was compiled in an online archive recently. ${ }^{9}$ During the dispute on whether Mexico as a member of the North American Free Trade Agreement could maintain its ban on GM maize trials from 1998, the Commission for Environmental Cooperation (CEC) of the North American Agreement on Environmental Cooperation conducted an extensive assessment of the implications of GM maize agriculture in Mexico, ${ }^{10}$ including a socio-cultural assessment [75]. One of the key findings was that many local and indigenous communities regarded the "presence of any transgenes in maize as an unacceptable risk to their traditional farming practices, and their cultural, symbolic, and spiritual value of maize" [76]. This led to the inclusion of a provision in the Mexican biosafety law that allows for banning the planting of GM maize in regions with traditional maize agriculture. Examples for other legislative or administrative measures that have been taken on the basis of socio-economic considerations are the ban of any activities with GM taro and coffee in the country of Hawai' ${ }^{11}$ and the rejection of an application on GM wine yeast in South Africa ${ }^{12}$ with regard to the reservations of indigenous communities or the wine 
industry, respectively. Only recently, the European Commission published a "Roadmap" on how to integrate socio-economic considerations in the existing legal framework on national basis that should help countries, which are willing to grow GM crops to overcome the approval deadlock in the EU [77] ${ }^{13}$. The initiative of the European Commission received mainly negative comments from all stakeholders [78,79]. They pointed out that the paper does not offer a convincing legal, administrative and scientific concept to integrate socio-economic considerations into decision making-as for example laid down by the Dutch GMO Commission-but simply shifts the contentious issue to the member states [80].

\section{Strategic environmental assessment and GM crop development}

It is apparent that the assessment of the systemic risks of GM crop agriculture needs a broader set of assessment tools as currently used and prescribed by the legal framework. One-also legally-established tool that might be useful in this context is the Strategic Environmental Assessment (SEA, Appendix). SEA is an internationally recognised approach that allows the assessment of the socio-environmental impacts of policies, programmes and plans. In their pioneering publication, Therivel et al. define SEA as: "the formalized, systematic and comprehensive process of evaluating the environmental effects of a policy, plan or program and its alternatives, [...] and using the findings in publicly accountable decision-making" [81]. SEA have been put into practise in a range of countries and as described by Goodland focus on three main classes of work $[82,83]$ :

(a) Policies: legislation and other rules;

(b) Plans and strategies, including regional and sectoral plans; and

(c) Programmes or sets of coordinated projects.

In the last decade, several policy processes were initiated to develop and adopt SEA concepts in the field of environmental decision making. In the EU, an SEA Directive came into force in 2001, but in contrast to the general features of SEAs only certain plans and programmes but no policies can be assessed ${ }^{14}$. At the international level, the CBD-following its articles $6 \mathrm{~b}$ and $14-$ and the OECD adopted SEA guidelines in the fields of biodiversity-related impact assessment and development cooperation, respectively [84-87]. It is interesting to note, but in the light of the above-described historical development of biosafety regulations, it is not surprising that neither the EU, the CBD nor the OECD includes GMO projects and biosafety policies under the scope of SEAs.

Based on the SEAs undertaken in recent years, many academic analyses on the quality of conduct and content have been published (Chaker 2006; Stoeglehner et al. 2009), but the authors also state that only a very limited amount of work on the effectiveness of SEAs with regard to its ability to influence policy decisions is available $[88,89]$. This might be caused by the more technical interest of the researchers in SEAs and by the fact that the recommendations of SEAs do not have a legally binding character, which makes it difficult to follow their actual influence on policy decisions. In the context of the GMO discussion, it will be useful to follow the SEA approaches in the field of biofuels. Many countries have started assessments of their biofuel policies and sustainability standards $[90,91]$. These standards will influence the trade and use of future biofuels. The envisaged systems of sustainability standards that might also contain exclusion criteria is, to a certain extent, comparable with the approval system of GMOs, and thus the features of their SEAs might also be applicable for biosafety policy and GMO project analysis.

A research of current literature indicates a lack of work on connecting SEA with GMO issues. Authors from Taiwan which is a leading Asian country with regard to the application of SEAs note that while sectoral and spatial planning are covered by SEA, this requirement should also extend to policy issues as "WTO accession, [...] development of biotechnology (e.g., genetically modified food), export of nuclear waste for treatment" [92]. Only Linacre et al., in the context of U.S.-sponsored biotechnology and biosafety capacity building projects, have published a first concept on how to apply SEA to support the adoption of GM crops in developing countries [93]. Since the SEA methodology requires a substantial influence of the public on the final recommendation, the authors see this approach as contentious. They note that "careful consideration needs to be given to how the expert and lay panels are constructed and managed in the qualitative assessment phase" to lead to the desired outcome of the process. With regard to the described basic concepts of SEA, specifically the requirement of an open dialogue without a predetermined outcome, it seems questionable if the concept suggested by Linacre et al. actually reflects the characteristics of an SEA and would lead to a more holistic assessment of systemic risks of GM crops [93].

\section{Summary and conclusions}

Since the early times of the development and application of genetic engineering, the scientific and public debate on risks and benefits encompassed a broad range of health, environmental, economic and social issues. It has been concluded in numerous stakeholder rounds and scientific publications that a comprehensive assessment and meaningful consideration of the implications of genetic engineering in all these fields would render more scientific strength and social acceptability to the decision-making process. Despite these debates and 
recommendations, only very few national legal frameworks and no international instrument obliges governments to include other issues than health and environment in the risk assessment procedure.

Due to the strong linkages between public and private research right from the start of the technology in the USA, the procedures for GMO risk assessment and decision making had been set up to be supportive for the promotion of the technology. Based on the ecotoxicological approach of testing of chemicals, the broader socioeconomic issues-as listed above but also more complex ecological concerns as long-term-and food web effects lay beyond the scope of the early GMO risk assessments. The debate on the regulation of genetic engineering in Europe focussed more on issues beyond corporate and economic issues. While this caused the legal character of the EU legislation to be a process-based concept under the environmental law, the previously developed ecotoxicological concept of GMO risk assessment were incorporated into the early EU legislation and the international Cartagena Protocol on Biosafety. Since 1998 until today, it is discussed controversially whether and how to develop traditional GMO risk assessment into a comprehensive environmental risk assessment, taking into account principles and methodologies of environmental and biodiversity research. Based on the published literature, an "ecotoxicological approach" and an "environmental approach" can be characterised. The basic distinction between their proponents is their degree of institutional and educational attachment to the development and marketing of GM crops.

In academic debates and work outside of the GMO field two approaches have emerged that, in combination, might be suitable to make the GMO debate more holistic and the decision framework more responsive to the specific social and economic situations in different countries. Work in the OECD and other fora resulted in the concept of "systemic risks", which has gained popularity in assessing risks in financial, economical and health systems. While it is apparent that at the scientific level the integration of a more holistic approach to the dimensions of GMO risks is feasible and indeed led to first results (e.g. by the projects GenEERA and GeneRisk), the existing official risk assessment and decisionmaking procedures cannot guarantee an appropriate reflection of these findings. A way forward in integrating the concept of "systemic risks" in GMO decision making could be the application of internationally recognised instruments as the Strategic Environmental Assessment. Guidelines and frameworks have been developed by the OECD, the CBD, and the EU. It is recommended to develop concepts and undertake case studies to test the applicability and usefulness of SEAs to be integrated in biosafety systems that allow for the holistic assessment of systemic risks in agro-biotechnology. The current EU discussions on including socio-economic considerations into GMO decision making offer an opportunity to amend national GMO legislation accordingly. When doing so, the experiences of the ongoing work in assessing biofuel policies and sustainability standards through SEAs should be taken into account.

\section{Appendix: Aims and objectives of SEA}

To support informed and integrated decision making by:

- Identifying environmental effects of proposed actions

- Considering alternatives, including the best practicable environmental option

- Specifying appropriate mitigation measures

To contribute to environmentally sustainable development by:

- Anticipating and preventing environmental impacts at source

- Early warning of cumulative effects and global risks

- Establishing safeguards based on principles of sustainable development

To help achieve environmental protection and sustainable development by:

- Consideration of environmental effects of proposed strategic actions

- Identification of the best practicable environmental option

- Early warning of cumulative effects and large-scale changes

To integrate the environment into sector-specific decision making by:

- Promoting environmentally sound and sustainable proposals

- Changing the way decisions are made

Source: Adapted from Abaza et al [94]

\section{Endnotes}

${ }^{1}$ Starting points for an overview about the U.S. biosafety regulations are: http://www.aphis.usda.gov/biotechnology/index.shtml

http://www.fda.gov/Food/Biotechnology/default.htm

http://www.epa.gov/pesticides/biopesticides/pips/index. htm

http://usbiotechreg.nbii.gov/, all accessed 30 April 2010

${ }^{2}$ A starting point for an overview about the EU biosafety legislation is http://ec.europa.eu/food/food/biotechnology/evaluation/gmo_nutshell_en.htm, accessed 30 April 2010

${ }^{3}$ The text of the CPB is available at http://www.cbd. int/biosafety/protocol.shtml, accessed 30 April 2010

${ }^{4}$ http://register.consilium.europa.eu/pdf/en/99/st09/ st09433-re01.en99.pdf; http://register.consilium.europa. eu/pdf/en/99/st09/st09433-ad01.en99.pdfhttp://register. 
consilium.europa.eu/pdf/en/99/st09/st09433.en99.pdf, all accessed 30 April 2010

${ }^{5}$ http://ec.europa.eu/food/food/biotechnology/gmo_ intro_en.htm

6"In the UK Farm Scale Evaluations of GM herbicide tolerant (GMHT) crops, an assessment endpoint was the sustainability of populations of arable weeds in fields. The observed reductions in arable weed populations in some GMHT crops were considered detrimental effects, because weeds were considered to be valuable biodiversity."

${ }^{7}$ http://pubresreg.org/, accessed on 30 April 2010

${ }^{8} \mathrm{http} / / /$ www.sozial-oekologische-forschung.org/de/692. php

${ }^{9}$ http://www.ifpri.org/book-637/node/5339, accessed on 30 April 2010

${ }^{10}$ http://www.cec.org/maize, accessed on 30 April 2010

${ }^{11} \mathrm{http}: / /$ records.co.hawaii.hi.us/weblink/DocView.aspx? id $=50710 \& \&$ dbid=0, accessed 30 April 2010

${ }^{12}$ http://www.nda.agric.za/docs/geneticresources/ ECMinutes_180907.pdf, accessed 30 April 2010

${ }^{13}$ http://ec.europa.eu/governance/impact/planned_ia/ docs/147_sanco_gmo_cultivation_en.pdf, accessed 30 April 2010

${ }^{14}$ For more information see http://ec.europa.eu/ environment/eia/sea-legalcontext.htm, accessed on 30 April 2010

\section{Acknowledgements}

The author gratefully acknowledges funding by the German Federal Ministry of Education and Research (BMBF) of the research project "GeneRisk" under grant FKZ: 07VPS14A and the fruitful discussions with members of the Vereinigung Deutscher Wissenschaftler (VDW). The views expressed in this paper are those of the author and do not represent views of the VDW or its members.

\section{Competing interests}

The author declares that they have no competing interests.

Received: 8 October 2010 Accepted: 4 February 2011

Published: 4 February 2011

\section{References}

1. James C: Global status of commercialized biotech/GM crops: 2009. ISAAA Brief No. 41 Ithaca: International Service for the Acquisition of Agro-biotech Applications; 2010

2. FoEl: Who benefits from GM crops? Amsterdam: Friends of the Earth International; 2010

3. Flowers TJ: Improving crop salt tolerance. J Exp Bot 2004, 55:307-319.

4. Vinocur B, Altman $A$ : Recent advances in engineering plant tolerance to abiotic stress: achievements and limitations. Curr Opin Biotechnol 2005, 2005:123-132

5. Visarada KBRS, Meena K, Aruna C, Srujana S, Saikishore N, Seetharama N: Transgenic breeding: perspectives and prospects. Crop Sci 2009, 49:1555-1563.

6. Dymond M, Hurr K: The global status of commercialised genetically modified plants 1 July 2008-31 December 2009 Wellington: MAF Biosecurity New Zealand; 2010.

7. Islam A: Fungus resistant transgenic plants: strategies, progress and lessons learnt. Plant Tissue Cult Biotech 2006, 16:117-138.
8. Stuiver M: Engineering fungal resistance in crops. In Plant biotechnology: current and future applications of genetically modified crops. Edited by: Halford N. New York: John Wiley 2006:225-239.

9. Stein AJ, Rodríguez-Cerezo E: The global pipeline of new GM crops: implications of asynchronous approval for international trade. European Commission, Joint Research Centre, Institute for Prospective Technology Studies, Sevilla; 2009

10. Rodgers J: Asilomar revisited. Mosaic 1981, $19-25$.

11. Singer M, Soll D: Guidelines for DNA hybrid molecules. Science 1973, 181:1114.

12. Berg P, Baltimore D, Nathans D, Boyer HW, Roblin R, Cohen SN, Watson JD, Davis RW, Weissman S, Hogness DS, Zinder ND: Potential biohazards of recombinant DNA molecules. Proc Natl Acad Sci 1974, 71:2593-2594.

13. Herbig J: Die Gen-Ingenieure München and Wien: Hanser; 1978.

14. Cohen SN: Recombinant DNA: fact and fiction. Science 1977, 195:654-657

15. Watson JD: An imaginary monster. Bull At Sci 1977, 33:19-20.

16. Watson JD: Remarks on recombinant DNA. CoEvol Quart Summer 1977 40-41.

17. Cohen SN: The manipulation of genes. Sci Am 1975, 233:25-32

18. Wright S: Molecular politics. Developing American and British regulatory policy for genetic engineering, 1972 - 1982 Chicago: The University of Chicago Press; 1994.

19. NRC: Risk assessment in the federal government: managing the process Washington, DC: National Academies Press; 1983

20. Suter GW: Ecological risk assessment Boca Raton: Lewis Publishers; 1993.

21. Commandeur P, Joly PB, Levidow L, Tappeser B, Terragni F: Public debate and regulation of biotechnology in Europe. Biotech Dev Monit 1996, 26:2-9.

22. Meyer H: The Cartagena Protocol on Biosafety. Biotech Dev Monit 2000, 43:2-7.

23. Hilbeck A, Baumgartner M, Fried PM, Bigler F: Effects of transgenic Bacillus thuringiensis corn-fed prey on mortality and development time of immature Chrysoperla carnea (Neuroptera: Chrysopidae). Environ Entymol 1998, 27:480-487.

24. Hilbeck A, Moar WJ, Pusztai-Carey M, Filippini A, Bigler F: Toxicity of Bacillus thuringiensis Cry1 Ab toxin to the predator Chrysoperla carnea (Neuroptera: Chrysopidae). Environ Entymol 1998, 27:1255-1263.

25. Losey JE, Rayor LS, Carter ME: Transgenic pollen harms monarch larvae. Nature 1999, 399:214.

26. EPA: Bt cotton confirmatory data and terms and conditions of the amendment Washington, DC: EPA; 2001

27. Obrycki J, Losey JE, Taylor OR, Jesse LCH: Transgenic insecticidal corn: beyond insecticidal toxicity to ecological complexity. BioScience 2001, 51:353-361.

28. Raybould A: Ecological versus ecotoxicological methods for assessing the environmental risks of transgenic crops. Plant Sci 2007, 173:589-602.

29. EFSA: Scientific opinion on the assessment of potential impacts of genetically modified plants on non-target organisms. EFSA J 2010.

30. Andow DA, Birch ANE, Dusi AN, Fontes EMG, Hilbeck A, Lang A, Lövei GL, Pires CSS, Sujii ER, Underwood E, Wheatley RE: Non-target and biodiversity risk assessment for genetically modified (GM) crops. Proceedings of 9th International Symposium on the Biosafety of Genetically Modified Organisms: September 2006; Korea 2006, 68-73.

31. Romeis J, Bartsch D, Bigler F, Candolfi MP, Gielkens MMC, Hartley SE, Hellmich RL, Huesing JE, Jepson PC, Layton R, Quemada H, Raybould A, Rose RI, Schiemann J, Sears MK, Shelton AM, Sweet J, Vaituzis Z, Wolt JD: Assessment of risk of insect-resistant transgenic crops to nontarget arthropods. Nature Biotechnol 2008, 26:203-208.

32. Hilbeck A, Meier MS, Raps A: Review on non-target organisms and Bt plants. Report prepared for Greenpeace International, Amsterdam Zurich: EcoStrat $\mathrm{GmbH}$, Ecological Technology Assessment \& Environmental Consulting; 2000

33. Jänsch S, Amorim MJ, Römbke J: Identification of the ecological requirements of important terrestrial ecotoxicological test species. Environ Rev 2005, 13:51-83.

34. Levidow L, Carr S, Wiel D: Genetically modified crops in the European Union: regulatory conflicts as precautionary opportunities. J Risk Res 2000, 3:189-208

35. Devos Y, Reheul D, Dewaele D, van Speybroeck L: The interplay between societal concerns and the regulatory frame on GM crops in the European Union. Environ Biosaf Res 2006, 5:127-149. 
36. Hill RA, Sendashonga C: General principles for risk assessment of living modified organisms: lessons from chemical risk assessment. Environ Biosaf Res 2003, 2:81-88.

37. Hill RA: Conceptualizing risk assessment methodology for genetically modified organisms. Environ Biosaf Res 2005, 4:67-70.

38. Snow A, Moran-Palma P: Commercialization of transgenic plants: potential ecological risks. BioScience 1997, 47:86-96.

39. Andow DA, Zwahlen C: Assessing environmental risks of transgenic plants. Ecol Lett 2006, 9:196-214

40. Römbke J, Jänsch S, Meier M, Hilbeck A, Teichmann H, Tappeser B: General recommendations for soil ecotoxicological tests suitable for the environmental risk assessment of genetically modified plants. Integr Environ Assess Manag 2009, 6:287-300.

41. Andow DA, Hilbeck A: Science-based risk assessment for nontarget effects of transgenic crops. BioScience 2004, 54:637-649.

42. Snow AA, Andow DA, Gepts P, Hallerman EM, Power A, Tiedje JM: Genetically modified organisms and the environment: current status and recommendations. Ecol Appl 2005, 15:377-404.

43. Marvier M, McCreedy MC, Regetz J, Kaveira P: A meta-analysis of effects of Bt cotton and maize on nontarget invertebrates. Science 2007, 316:1475-1477.

44. Garcia-Alonso M, Jakobs E, Raybould A, Nickson TE, Sowig P, Willekens H, van der Kouwe $P$, Layton R, Amijee F, Fuentes AM: A tiered system for assessing the risk of genetically modified plants to non-target organisms. Environ Biosaf Res 2006, 5:57-65.

45. Nickson TE: Planning environmental risk assessment for genetically modified crops: problem formulation for stress-tolerant crops. Plant Physiol 2008, 147:494-502.

46. EFSA: Guidance on the environmental risk assessment of genetically modified plants. EFSA J 2010

47. Nelson KC, Banker MJ: Problem formulation and options assessment handbook St. Paul: University of Minnesota; 2007.

48. Hilbeck A, Andow DA: Environmental risk assessment of genetically modified organisms, volume 1: a case study of Bt maize in Kenya Wallingford: Cabi Publishing; 2004

49. Hilbeck A, Andow DA, Fontes EMG: Environmental risk assessment of genetically modified organisms, Volume 2: methodologies for assessing Bt cotton in Brazil Wallingford: Cabi Publishing; 2006.

50. Andow DA, Hilbeck A, Nguyen VT: Environmental risk assessment of genetically modified organisms, volume 4: challenges and opportunities with Bt cotton in Vietnam Wallingford: Cabi Publishing; 2008.

51. OECD: Emerging risks in the 21st century-an agenda for action. Paris 2003.

52. Raybould A: Problem formulation and hypothesis testing for environmental risk assessments of genetically modified crops. Environ Biosaf Res 2006, 5:119-125.

53. Gibbons M: Science's new social contract with society. Nature 1999 402(Suppl 6761):C81-C84.

54. Kvakkestad V, Gillund F, Kjølberg KA, Vatn A: Scientists' perspectives on the deliberate release of GM crops. Environ Values 2007, 16:79-104.

55. Greef W: The Cartagena Protocol and the future of agbiotech. Nat Biotechnol 2004, 22:811-812.

56. Millstone $\mathrm{E}$, van Zwanenberg $\mathrm{P}$, Marris $\mathrm{C}$, Levidow L, Torgersen $\mathrm{H}$ : Science in trade disputes related to potential risks: comparative case studies. European Commission; 2004.

57. Meyer $\mathrm{H}$ : The precautionary principle and the Cartagena Protocol on Biosafety: development of a concept. In Biosafety first-holistic approaches to risk and uncertainty in genetic engineering and genetically modified organisms. Edited by: Traavik T, Li Ching L. Trondheim: Tapir Academic Press; 2007:469-482.

58. Slovic P: The risk game. J Hazard Mater 2001, 89:17-24

59. Wynne B: Creating public alienation: expert cultures of risk and ethics on GMOs. Sci Cult 2001, 10:445-481.

60. Committee on Improving Risk Analysis Approaches Used by the U.S. EPA: Science and decisions: advancing risk assessment. Washington, DC 2009.

61. IRGC: An introduction to the IRGC risk governance framework. Geneva 2008.

62. Helbing D: Systemic risks in society and economics. Working Paper 09-12044 Santa Fe Institute; 2009.

63. Briggs DJ: A framework for integrated environmental health impact assessment of systemic risks. Environ Health 2008, 7:61-78.

64. McMichael A: Environmental change, climate and population health: a challenge for inter-disciplinary research. Environ Health Prev Med 2008, 13:183-186.
65. Breckling $B$, Laue $H$, Pehlke $H$ : Remote sensing as a data source to analyse regional implications of genetically modified plants in agriculture-Oilseed rape (Brassica napus) in Northern Germany. Ecol Indicat 2009

66. Breckling B, Reuter $H$, Middelhoff U, Glemnitz M, Wurbs A, Schmidt G, Schröder W, Windhorst W: Risk indication of genetically modified organisms (GMO): modelling environmental exposure and dispersal across different scales. Ecol Indicat 2009.

67. Schmidt G, Schröder W: Regionalisation of climate variability used for modelling the dispersal of genetically modified oil seed rape in Northern Germany. Ecol Indicat 2009.

68. Glemnitz M, Wurbs A, Roth R: Derivation of regional crop sequences as an indicator for potential GMO dispersal on large spatial scales. Ecol Indicat 2009.

69. Middelhoff U, Reiche EW, Windhorst W: An integrative methodology to predict dispersal of genetically modified genotypes in oilseed rape at landscape-level-a study for the region of Schleswig-Holstein, Germany. Ecol Indicat 2009

70. Reuter H, Schmidt G, Schröder W, Middelhoff U, Pehlke H, Breckling B: Regional distribution of genetically modified organisms (GMOs)-upscaling the dispersal and persistence potential of herbicide resistant oilseed rape (Brassisca napus). Ecol Indicat 2009.

71. Middelhoff $U$, Reuter $H$, Breckling B: GeneTraMP, a spatio-temporal model of the dispersal and persistence of transgenes in feral, volunteer and crop plants of oilseed rape and related species. Ecol Indicat 2009

72. Otsuka Y: Socioeconomic considerations relevant to the sustainable development, use and control of genetically modified foods. Food Sc Tech 2003, 14:294-318.

73. Gupta A: Framing "biosafety" in an international context: the biosafety protocol negotiations Cambridge: Harvard University; 1999.

74. Falck-Zepeda JB: Socio-economic considerations, Article 26.1 of the Cartagena Protocol on Biosafety: what are the issues and what is at stake? AgBioforum 2009, 12(1):90-107.

75. Brush S, Chauvet M: Assessment of social and cultural effects associated with transgenic maize production Quebec: Secretariat of the Commission for Environmental Cooperation; 2004

76. CEC: Maize and biodiversity. The effects of transgenic maize in Mexico-key findings and recommendations. Quebec 2004

77. European Commission: New policy for genetically modified organisms (GMO) cultivation Brussels: European Commission; 2010.

78. Anonymous: EU GMO proposals draw widespread criticism. Brussels: EurActiv Network; 2010.

79. Chipman A: Fears over Europe's GM crop plan. Nature 2010, 466:542-543

80. COGEM: Socio-economic aspects of GMOs. Building blocks for an EU sustainability assessment of genetically modified crops. Bilthoven 2009.

81. Therivel R, Wilson E, Thompson S, Heaney D, Pritchard D: Strategic environmental assessment London: Earthscan Publishers; 1992.

82. Buckley R: Strategic environmental assessment of policies and plans: legislation and implementation. Impact Assess Proj Apprais 2000, 18:209-215.

83. Goodland R: Strategic environmental assessment and the World Bank Group. Internat J Sustain Dev World Ecol 2005, 12:1-11.

84. CBD: Decision VI/7. Identification, monitoring, indicators and assessments. Guidelines for incorporating biodiversity related issues into environmentalimpact-assessment legislation or processes and in strategic impact assessment. Montreal 2004

85. CBD: CBD Technical Series No. 26-biodiversity in impact assessment. Background document to CBD Decision VIII/28: voluntary guidelines on biodiversity-inclusive impact assessment. Montreal 2006.

86. OECD: Applying strategic environmental assessment. Good Practice guidance for development cooperation. Paris 2006.

87. OECD: Strategic environmental assessment and ecosystem services. Paris 2008.

88. Chaker A, El-Fad K, Chamas L, Hatjian B: A review of strategic environmental assessment in 12 selected countries. Environ Impact Assess Rev 2006, 26:15-56

89. Stoeglehner G, Brown AL, Kørnøv LB: SEA and planning: 'ownership' of strategic environmental assessment by the planners is the key to its effectiveness. Impact Assess Proj Apprais 2009, 27:111-120.

90. Gnansounou E: Assessing the sustainability of biofuels: a logic-based model. Energy 2010. 
91. Jay S: Strategic environmental assessment for energy production. Energy Policy 2010, 38:3489-3497.

92. Ming-Lone L, Yue-Hwa Y: Development and implementation of strategic environmental assessment in Taiwan. Environ Impact Assess Rev 2004, 24:337-350.

93. Linacre NA, Gaskell J, Rosegrant MW, Falck-Zepeda J, Quemada H, Halsey M, Birner R: Strategic environmental assessments for genetically modified organisms. Impact Assess Proj Apprais 2006, 24:35-43.

94. Abaza H, Bisset R, Sadler B: Environmental impact assessment and strategic environmental assessment: towards an integrated approach Nairobi: UN Environmental Program; 2004.

doi:10.1186/2190-4715-23-7

Cite this article as: Meyer: Systemic risks of genetically modified crops:

the need for new approaches to risk assessment. Environmental Sciences Europe 2011 23:7.

\section{Submit your manuscript to a SpringerOpen ${ }^{\circ}$ journal and benefit from:}

- Convenient online submission

- Rigorous peer review

- Immediate publication on acceptance

- Open access: articles freely available online

- High visibility within the field

- Retaining the copyright to your article

Submit your next manuscript at $\gg$ springeropen.com 